Note

\section{A New Method for the Dimroth Rearrangement of Adenine Nucleotide Derivatives with an Anion Exchanger}

\section{Yoshimitsu YamazaKi and Hidekatsu MaEda}

\author{
Fermentation Research Institute, Agency of \\ Industrial Science and Technology, \\ Ministry of International Trade and Industry, \\ Yatabe-machi Higashi 1-1--3, Ibaraki 305, Japan
}

Received March 27, 1981

The Dimroth rearrangement is the apparent migration of an alkyl group from heterocyclic nitrogen to an $\alpha$-amino or imino group. ${ }^{1,2)}$ This reaction is extremely useful in the synthesis of $N^{6}$-alkylated derivatives of adenine nucleotide coenzymes such as NAD and ATP. ${ }^{3 \sim 6)}$ The $N^{6}$-alkylated coenzymes are bound to polymers by use of the $N^{6}$. substituents as spacer arms, and the so-obtained polymerbound coenzymes are used in continuous enzyme reactors containing ultrafiltration membranes. Alkylation of adenine riboside usually takes place at $N^{1}$, and hence the desirable $N^{6}$-alkylated derivatives are obtained by the Dimroth rearrangement by the following mechanism: ${ }^{7}$

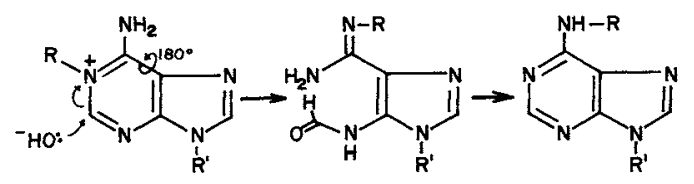

In the course of our study for synthesizing polymerbound ATP, ${ }^{5)}$ we felt the need for improvement of the method for the rearrangement of $N^{1}$-carboxymethyl-ATP (1) since the conventional method (heating in alkaline conditions for $1 \sim 2 \mathrm{hr})^{4)}$ was troublesome as regards controlling the $\mathrm{pH}$ and entailed partial decomposition of the product to the corresponding diphosphate.

From the above mechanism, we surmised that better efficiency might be had by using anion exchangers $\left(\mathrm{OH}^{-}\right.$ form) for the rearrangement based on the high concentration of $\mathrm{OH}^{-}$ions around the adsorbed nucleotide molecules. An experiment with 1 and Dowex $1\left(\mathrm{OH}^{-}\right)$resin showed that the rearrangement of adsorbed 1 was almost complete within 5, 10, and $240 \mathrm{~min}$ when heated at 100,75 , and $50^{\circ} \mathrm{C}$, respectively (Fig. 1). Even at room temperature, $90 \%$ of 1 was converted to the $N^{6}$-derivative in 2 days on the resin. It was also important that the product was little decomposed on heating as shown by HPLC (Fig. 1). This fact can be possibly interpreted in terms of stabilization of triphosphate group by ionic bonding to the cationic resin.
Thus, one can carry out the Dimroth rearrangement of $N^{1}$-alkylated adenine nucleotides* with high yields by the simple and rapid method of heating in the state when adsorbed on anion exchangers. ${ }^{* *}$ The detailed procedure is now described for the synthesis of $N^{6}$-carboxymethylATP (2).

1 was synthesized by the method of Lindberg and Mosbach ${ }^{4}$ and purified by Dowex 1 column chromatography. $300 \mathrm{mg}$ of 1 (Li salt, $0.45 \mathrm{mmol}$ based on phosphate analysis) was dissolved in $15 \mathrm{ml}$ of water. To the solution was added $36 \mathrm{~g}$ (wet weight) of Dowex $1 \times 2\left(\mathrm{OH}^{-}\right)$resin, which had been repeatedly washed with $10 \% \mathrm{NaOH}, 3 \mathrm{M}$ $\mathrm{HCl}$, and water, before use. The mixture was stirred for $10 \mathrm{~min}$ and then filtered with suction. The resin was washed with about $200 \mathrm{ml}$ of water until the filtrate became neutral. This washing was necessary to prevent decomposition of the product. The resin was transferred to a beaker with $20 \mathrm{ml}$ of water. The mixture was held at $100^{\circ} \mathrm{C}$ for $15 \mathrm{~min}$. After cooling, $1 \mathrm{M} \mathrm{HCl}$ was added to the ice-cold mixture under stirring until the $\mathrm{pH}$ of the supernatant became 1 . The mixture was filtered with suction and eluted three times with $1 \mathrm{M} \mathrm{LiCl}(\mathrm{pH} 1,50 \mathrm{ml}$ each). The filtrate and the eluates were combined, neutralized with $2 \mathrm{M}$ $\mathrm{LiOH}$, and concentrated to about $10 \mathrm{ml}$ by an evaporator. To the concentrate was added $300 \mathrm{ml}$ of ice-cold EtOHacetone $(1: 1)$. The white precipitate was collected by centrifugation and dried under vacuum. The crude product was further purified in the usual manner. ${ }^{8)} 251 \mathrm{mg}$ $(0.38 \mathrm{mmol})$ of 2 was obtained as the Li salt $(84 \%$ yield). This compounds showed a single spot in TLC under UV light. $R f$ values of 2 and ATP were as follows: 0.28 (2) and 0.40 (ATP) [cellulose $F_{254}$, developed with isobutyric acid- $1 \mathrm{M}$ aqueous $\mathrm{NH}_{3}(5: 3, \mathrm{v} / \mathrm{v})$ saturated with EDTA]; 0.11 (2) and 0.20 (ATP) [PEI-cellulose F, developed with $2 \mathrm{M} \mathrm{HCOOH}-\mathrm{I} \mathrm{M} \mathrm{LiCl}(1: 1, v / v)]$. Observed ratio of total phosphate-acid-labile phosphate $=3: 1.97$. UV $\lambda_{\max }^{\mathrm{pH}} 7$ $\mathrm{nm}(\varepsilon)$ : $267\left(18.0 \times 10^{3}\right.$, based on phosphate analysis). CMR (15 MHz) $\delta_{\text {TSP }}^{2}: 47.40$ (NCCO), 68.05 (C-5'), 72.85 $\left(\mathrm{C}-3^{\prime}\right), 77.14\left(\mathrm{C}-2^{\prime}\right), 86.36\left(\mathrm{C}-4^{\prime}, \mathrm{d}, J=7.8 \mathrm{~Hz}\right), 89.74\left(\mathrm{C}-1^{\prime}\right)$, 121.42 (C-5), 142.07 (C-8), 150.77 (C-2), 155.32 (C-6), $156.74(\mathrm{C}-4)$, and $179.85(\underline{\mathrm{COOH}})$.

\section{REFERENCES}

1) O. Dimroth, Ann. Chem. Liebigs, 364, 183 (1909).

2) D. J. Brown and J. S. Harper, J. Chem. Soc., 1963,

* The present method was unsuccessful in the case of NAD derivatives since no enzymically active product was recovered, probably because of decomposition of the alkali-labile pyridinium riboside linkage.

** Among the anion exchangers tested (Dowex 1 and 2, Amberlite IR-A400, A410, and 45), Dowex 1 gave the most satisfactory result in respect of binding capacity and heat-stability. It could be repeatedly used at least three times even when heated to $100^{\circ} \mathrm{C}$. 

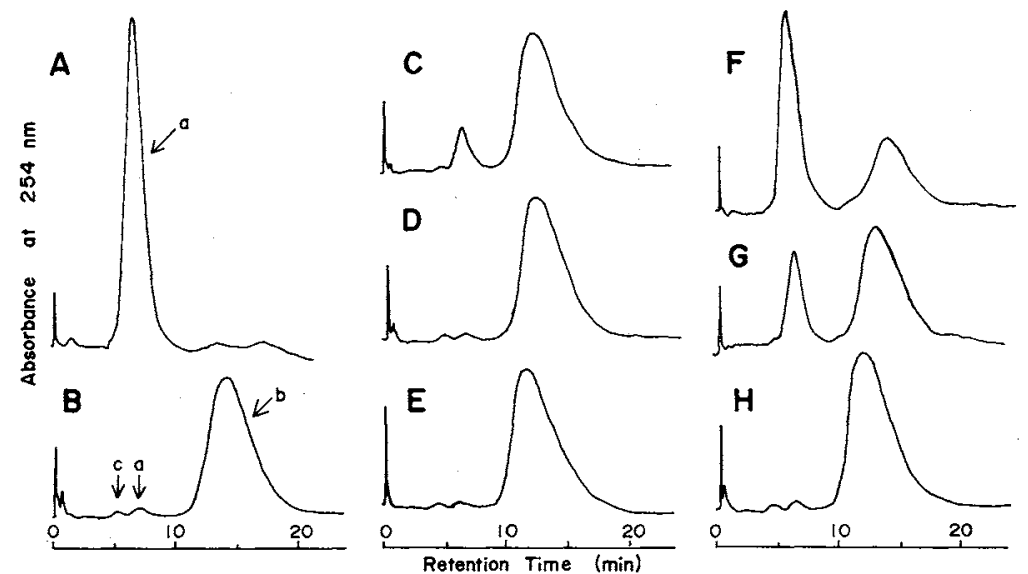

FIG. 1. High-performance Liquid Chromatography Showing the Dimroth Rearrangement of $N^{1}$ Carboxymethyl-ATP (1) Heated on Dowex $1\left(\mathrm{OH}^{-}\right)$Resin.

Heating conditions: (A) not heated; (B) $100^{\circ} \mathrm{C}, 5 \mathrm{~min}$; (C) $75^{\circ} \mathrm{C}, 5 \mathrm{~min}$; (D) $75^{\circ} \mathrm{C}, 10 \mathrm{~min}$;(E) $75^{\circ} \mathrm{C}, 30 \mathrm{~min}$; (F) $50^{\circ} \mathrm{C}, 10 \mathrm{~min} ;(\mathrm{G}) 50^{\circ} \mathrm{C}, 30 \mathrm{~min} ;(\mathrm{H}) 50^{\circ} \mathrm{C}, 240 \mathrm{~min}$.

Experimental procedure: In a typical experiment, $10 \mathrm{mg}$ of purified 1 was dissolved in $1 \mathrm{ml}$ of water and mixed with $1.2 \mathrm{~g}$ (wet weight) of Dowex $1 \times 2\left(\mathrm{OH}^{-}\right)$resin. After $5 \mathrm{~min}$, the mixture was filtered with suction and washed with $10 \mathrm{ml}$ of water. The resin was transferred to a test tube with $1 \mathrm{ml}$ of water and maintained at $100^{\circ} \mathrm{C}$ for $5 \mathrm{~min}$. After cooling, $0,36 \mathrm{ml}$ of $1 \mathrm{M} \mathrm{HCl}$ was added to the mixture. The resin was filtered and eluted 4 times with $1 \mathrm{ml}$ of $1 \mathrm{M} \mathrm{LiCl}(\mathrm{pH} \mathrm{l})$. The filtrate and eluates were combined, neutralized with $2 \mathrm{M} \mathrm{LiOH}$, and made up to a total volume of $6-\mathrm{ml}$ with water. An aliquot $(20 \mu \mathrm{l})$ was subjected to HPLC with a Toyo Soda HLC-802UR chromatograph under the following conditions: column, Bondapak AX/Corasil (Waters Associates, 2-mm I.D. $\times 61 \mathrm{~cm}$ ); elution, linear gradient for $40 \mathrm{~min}$ from $10 \mathrm{mM} \mathrm{NH}_{4} \mathrm{H}_{2} \mathrm{PO}_{4}(\mathrm{pH} 5.3$ ) to $125 \mathrm{~mm}$ $\mathrm{NH}_{4} \mathrm{H}_{2} \mathrm{PO}_{4}+250 \mathrm{mM} \mathrm{KCl}(\mathrm{pH} 5.0)$; flow rate, $4.5 \mathrm{ml} / \mathrm{min}$; detection, $\mathrm{UV}$ at $254 \mathrm{~nm}$.

The arrows, $\mathrm{a}, \mathrm{b}$, and $\mathrm{c}$, indicate the peaks of $1, N^{6}$-carboxymethyl-ATP, and $N^{6}$-carboxymethyl-ADP, respectively. The latter assignment is based on the synthesized ADP derivative.

1276.

3) M. Lindberg, P.-O. Larsson and K. Mosbach, Eur. J. Biochem., 40, 187 (1973).

4) M. Lindberg and K. Mosbach, Eur. J. Biochem., 53, 481 (1975).

5) Y. Yamazaki and H. Maeda, Agric. Biol. Chem., 45, 2091 (1981).
6) Y. Yamazaki and H: Maeda, Agric. Biol. Chem., 45, 2277 (1981).

7) J. D. Engel, Biochem. Biophys. Res. Commun., 64, $581(1975)$.

8) Y. Yamazaki and H. Suzuki, Eur. J. Biochem., 92, 197 (1978). 